\title{
Production of Fuels From High Density Polyethylene and Low Density Polyethylene Plastic Wastes via Pyrolysis Methods
}

\author{
E. H. Istoto ${ }^{1 *}$, Widayat ${ }^{2}$, S. Saptadi ${ }^{3}$ \\ ${ }^{1}$ School of Postgraduate Studies, Diponegoro University, Semarang, Indonesia \\ 2 Department of Chemical Engineering, Faculty of Engineering, Diponegoro University, Semarang, Indonesia \\ ${ }^{3}$ Department of Industrial Engineering, Faculty of Engineering, Diponegoro University, Semarang, Indonesia
}

\section{$P A P E R \quad I N F O$}

\section{Paper history:}

Received 17 July 2019

Accepted in revised form 16 September 2019

\section{Keywords:}

Fuels

High Density Polyethylene

Low Density Polyethylene

Pyrolysis

Plastic Waste

\section{$A \quad B \quad S T R A C A$}

The composition of fuel production per litre from polyethylene waste via pyrolysis was determined through thermal degradation. Compositions of fuels from high density polyethylene/low density polyethylene (HDPE/LDPE) pyrolysis were naphta, gasoline, and active carbon as residues. The pyrolysis process was carried out at $450-621^{\circ} \mathrm{C}$ without any catalyst and quantitative analysis method was conducted by using GCMS. The product of $5 \mathrm{~kg}$ pyrolysis HDPE are 3.25 litres of naphta; 0.85 litre of gasoline; 0.325 litre of diesel fuel; and 18.06 grams of active carbon. Then the product of $5 \mathrm{~kg}$ pyrolysis LDPE are 0.5 litres of naphta; 2.9 litres of gasoline; 0,1 litre of diesel fuel; and 19 grams of active carbon.

\section{INTRODUCTION}

The production fuels from plastic waste has been widely reported by many researchers. A number of studies have examined the production fules from high density polyethylene (HDPE) and low density polyethylene (LDPE) wastes. Indonesia is one of the great producer number 2 plastic wastes in the world 3,22 million metrics tonne per year and 0.48-1.29 million metrics tonne per year of plastic wastes dumped in ocean [1]. So, energy production from plastic waste is one of the desired methods to managed plastic waste in the world especially in Indonesia.

Biofuel industry is labor intensive, especially in Indonesia, job market is created by biofuel industry from palm oil [2]. This is indicated to develop biofuel industry from plastic wastes would boost fuel economy.

The relationship between production of fuels from HDPE and LDPE plastic wastes via pyrolysis methods has been an active research area would be explained in detail at theory and methodology.

This study discusses to calculate and composition of fuels from polyethylene waste production per litre. The process used pyrolysis methods at $450-621^{\circ} \mathrm{C}$ without any catalyst for LDPE and HDPE wastes for duration of 3 and 4 hours, respectively. The products were analyzed with quantitative and qualitative analysis. Qualitative analysis this products with GC-MS method.

The results of this study can be used as the foundation of policy making especially in the energy and environment field, and development of industrial fuels (biofuel and biodiesel) from plastic wastes in Indonesia.

\section{THEORY AND METHODOLOGY}

\section{Pyrolysis HDPE and LDPE plastic wastes}

Pyrolysis was the process of degradation of a material at high temperature without presence of oxygen (thermochemical process), in degrading plastic material it takes a temperature between $300-500^{\circ} \mathrm{C}$ to become gas then condensed, then distillated to produced oil and the pulp in the form of char [3]

Several studies related to the production of biodiesel from plastic HDPE and LDPE wastes have been carried out by both domestic and foreign researchers. Pyrolysis plastic oil increased efficiency by $15-20 \%$ in $100 \mathrm{cc}$ bajaj motors compared to using gasoline, increased thermal efficiency gasoline engine, pyrolysis oil from HDPE has

*Corresponding Author Email: enggarheroistoto@student.undip.ac.id (E. H. Istoto) 
the same density as gasoline and pyrolysis oil from LDPE has the same density as diesel fuel, and pyrolysis process at a fairly low temperature required a catalyst to be efficient in combustion [4].

Pyrolysis oil from LDPE has a content similar to diesel fuel, although in viscosity and the calorific value was still a little low; the advantage of pyrolysis oil has lower carbon residue and sulfur so it was more environmentally friendly; in economic, for each pyrolysis oil production from LDPE waste ranging from 14-18 rupees it is much cheaper than the price of diesel fuel which reaches 40 rupees per litre [5].

Processing of LDPE plastic waste with microwave pyrolysis method, from this method showed that microwave pyrolysis method produced plastic biodiesel for 60 minutes to obtain $23.65 \%$ liquid, $30.41 \% \mathrm{CH}_{4}$ gas, and solid $4.67 \%$ at $500^{\circ} \mathrm{C}$ [6].

The best efficiency decomposition results in decomposing plastic waste occur at $420^{\circ} \mathrm{C}$ with a operating time of 60 minutes, and pyrolysis oil from plastic waste (HDPE and LDPE) has characteristics were not much different from the characteristics of diesel oil [7].

Production of biodiesel from plastic HDPE using the pyrolysis method heated up to $330-490^{\circ} \mathrm{C}$ resulted quality of fuel oil (biodiesel) better than diesel oil [8].

\section{Pyrolysis process and analysis}

Based on previous research data, this study was conducted using the pyrolysis method at a temperature of $450-621^{\circ} \mathrm{C}$ without using any catalyst and quantitatively analyzed. Quantitative analysis of fuel was carried out through GC-MS method.

\section{RESEARCH MODEL}

\section{Research material}

HDPE and LDPE plastics that have been chopped and obtained from plastic collectors in Semarang City. Fuel using $5.5 \mathrm{~kg}$ LPG from PT. Pertamina (Persero).

\section{Pyrolsis process}

Cleaned and chopped HDPE and LDPE plastic samples of $5 \mathrm{~kg}$ each were put into the reactor. The plastic is heated using the pyrolysis method at temperature of $450-621^{\circ} \mathrm{C}$ without any catalyst for 4 hours for HDPE and 3 hours for LDPE. The gas produced from the reactor were condensed into a liquid phase using a condenser. The product conversion calculation produced is used as follows:

$$
\begin{aligned}
& \text { Liquid Products }(\mathrm{L} / \mathrm{Kg} \%)=(\text { Litre of product/Mass of raw } \\
& \text { material) } \times 100 \% \\
& \text { Solid Product or Residue }\left({ }^{K g} / \mathrm{Kg} \%\right)=(\text { Kg of product } \\
& \text { Mass of raw material }) \times 100 \% \\
& \text { Gas Products }=100 \%-\{\text { Liquid Products }(\mathrm{L} / \mathrm{Kg} \\
& \%)+ \text { Solid Products }(\%)\}
\end{aligned}
$$

Products from plastic pyrolysis in the form of naphtha, gasoline, and diesel fuel and produced residues (activated carbon) were analyzed by GC-MS at the Diponegoro University Integrated Laboratory.

\section{RESULT}

\section{Pyrolysis of HDPE plastics waste}

HDPE plastic pyrolysis carried out for 4 hours using 5.5 $\mathrm{kg}$ LPG without any catalyst. The process produced 3.25 $\mathrm{L}$ in the form of naphtha; oil fraction $1(\mathrm{~F} 1)$ as much as 1 $\mathrm{L}$; oil fraction $2(\mathrm{~F} 2)$ as much as $0.25 \mathrm{~L}$; and activated carbon as much as 18.06 grams. If the results are included in the formula it will be produced as follows (Table 1):

Naphtha : $(3,25 \mathrm{~L} / 5 \mathrm{Kg}) \times 100 \%=65 \mathrm{~L} / \mathrm{Kg} \%$

F1: $(0.325 \mathrm{~L} / 5 \mathrm{Kg}) \times 100 \%=6.5 \mathrm{~L} / \mathrm{Kg} \%$

F2: $(0.85 \mathrm{~L} / 5 \mathrm{Kg}) \times 100 \%=17 \mathrm{~L} / \mathrm{Kg} \%$

Activated Carbon: $(0.01806 \mathrm{Kg} / 5 \mathrm{Kg}) \times 100 \%=0.3612 \% \approx$ $0,36 \%$

Gas: $100 \%-(65 \%+6.5 \%+17 \%+0.36 \%)=11.14 \%$. Overall the products produced during the pyrolysis process of HDPE plastics were $88.86 \%$ non-gas and $11.14 \%$ gas.

\section{Pyrolysis of LDPE plastics waste}

LDPE plastic pyrolysis carried out for 3 hours using 5.5 $\mathrm{kg}$ LPG without catalyst. The process produced oil fraction $1(\mathrm{~F} 1)$ as much as $0.1 \mathrm{~L}$; oil fraction $2(\mathrm{~F} 2)$ as much as $2.9 \mathrm{~L}$; and activated carbon as much as 19 grams. If the results are included in the formula it will be produced as follows (Table 1):

F1: $(0.1 \mathrm{~L} / 5 \mathrm{Kg}) \times 100 \%=2 \mathrm{~L} / \mathrm{Kg} \%$

F2: $(2.9 \mathrm{~L} / 5 \mathrm{Kg}) \times 100 \%=58 \mathrm{~L} / \mathrm{Kg} \%$

Karbon aktif: $\left({ }^{0.019} \mathrm{Kg} / 5 \mathrm{Kg}\right) \times 100 \%=0.38 \%$

Gas: $100 \%-(2 \%+58 \%+0.38 \%)=39.62 \%$.

Overall the products produced during the pyrolysis process of LDPE plastics are $60.38 \%$ non-gas and $39.62 \%$ gas.

\section{GC-MS of HDPE plastics waste}

In Figure 1a, pyrolysis oil of HDPE plastics waste saw dark brown. Most likely the oil content in it includes the $\mathrm{C}$ chain which was quite long to very long. Physically similar to diesel oil, kerosene, and heavy oil. In Figure 1b, pyrolysis oil of HDPE plastics waste saw yellowish-

TABLE 1. Pyrolysis of HDPE and LDPE Plastics Waste

\begin{tabular}{lccc}
\hline & LDPE & HDPE & Unit \\
\hline Naphtha & 0 & 65 & $\mathrm{~L} / \mathrm{Kg} \%$ \\
Diesel Oil (F1) & 2 & 6.5 & $\mathrm{~L} / \mathrm{Kg} \%$ \\
Gasoline (F2) & 58 & 17 & $\mathrm{~L} / \mathrm{Kg} \%$ \\
$\begin{array}{l}\text { Activated Carbon/ } \\
\text { Residue }\end{array}$ & 0.38 & 0.36 & $\%$ \\
Gas & 39.62 & 11.14 & $\%$ \\
\hline
\end{tabular}




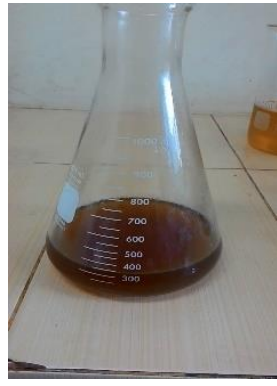

(a)

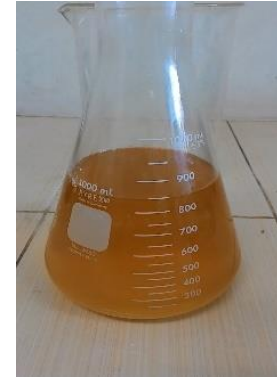

(b)
Figure 1. Pyrolysis oil of HDPE plastics waste (a) Fraction 1 and (b) Fraction 2

brown. It is likely that the oil content in it includes the C chain, which was quite short to quite long. Physically similar to gasoline, kerosene, and there is the possibility of a little diesel oil.

In Figure 2a, the content of the fraction 1 from the pyrolysis of HDPE plastic waste was proven to be dominated by kerosene (C10-C18) as much as $38.41 \%$, gasoline (C5-C12) as much as $28.63 \%$, heavy oil (C20C50) as much $20.08 \%$, and diesel oil (> C12) as much as $12.87 \%$. In Figure 2b, the content of the fraction 2 from the pyrolysis of HDPE plastic waste was proven to be dominated by gasoline (C5-C12) as much as $65.84 \%$, kerosene (C10-C18) as much as $26.29 \%$, and diesel oil (> $\mathrm{C} 12)$ as much $7.88 \%$. The $\mathrm{C} 5-\mathrm{C} 12$ chain is classified as gasoline, $\mathrm{C} 10-\mathrm{C} 18$ is classified as kerosene, $>\mathrm{C} 12$ is classified as diesel oil, and C20-C50 is classified as oil [9].

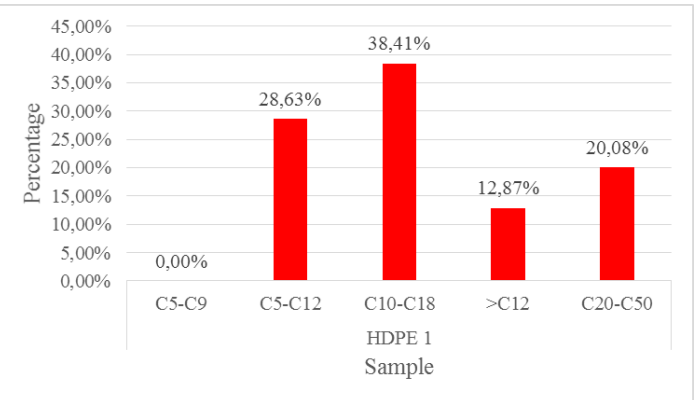

(a)

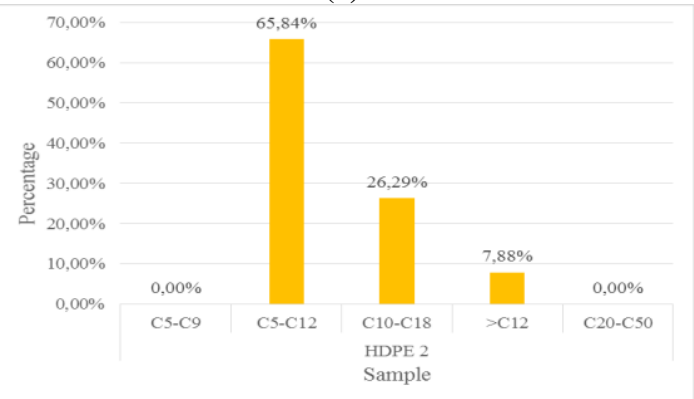

(b)

Figure 2. GC-MS results from pyrolysis of HDPE plastic waste (a) Fraction 1 and (b) Fraction 2
In Figure $3 \mathrm{a}$, it appears that the results were solids resulting from the pyrolysis of HDPE plastic waste in the form of a type of naphtha and colored slightly brown. Most likely other than naphtha there is another ingredient in the naphtha. In Figure 3b, the results of pyrolysis of HDPE plastic waste also produced black activated carbon. The activated carbon produced in the pyrolysis is 18.06 grams.

In Figure 4, the content of a type of naphtha from the pyrolysis of HDPE plastics waste was proven to be dominated by naphtha (C5-C9) as much as $93.57 \%$, and diesel oil $(>\mathrm{C} 12)$ as much as $6.43 \%$. This is in accordance with the physical appearance observed by the researcher.

\section{GC-MS of LDPE plastics waste}

In Figure 5a, the pyrolysis oil of LDPE plastic waste was dark brown. Most likely the oil content in it includes the $\mathrm{C}$ chain which is quite long to very long. Physically similar to kerosene, diesel oil, kerosene and heavy oil. In Figure 5b, the pyrolysis oil of LDPE plastic waste is dark brown. Most likely the oil content in it includes the $\mathrm{C}$ chain which was quite short to quite long. Physically similar to kerosene, diesel oil and the possibility of gasoline, or a little heavy oil.

In Figure 6a, the content of the 1st fraction from the pyrolysis of LDPE plastic waste was proven to be

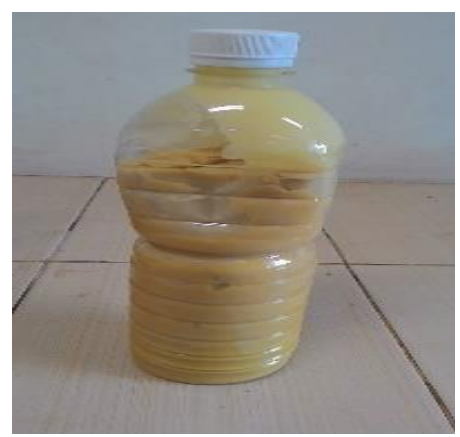

Figure 3. Solid phase from pyrolysis oil of HDPE plastics waste like naphtha

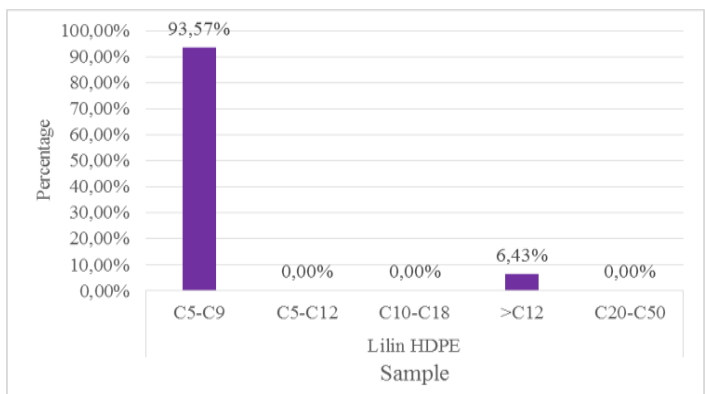

Figure 4. The result of GC-MS is a type of naphtha (Figure 3a) resulting from the pyrolysis of HDPE plastics waste 


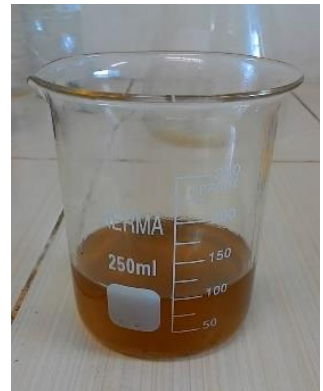

(a)

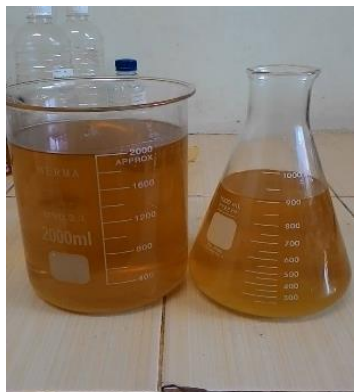

(b)
Figure 5. Pyrolysis oil of LDPE plastics waste (a) Fraction 1 and (b) Fraction 2

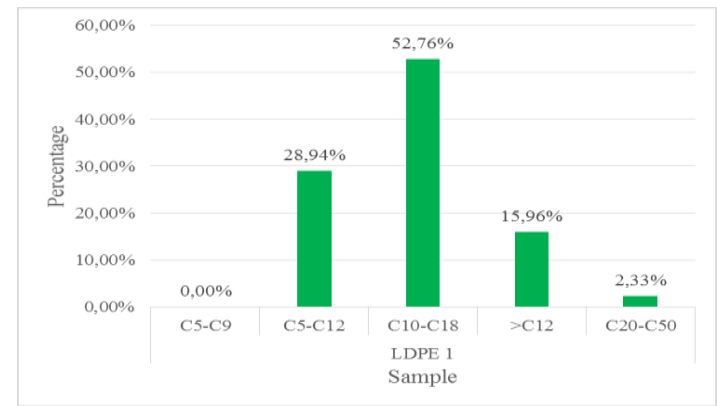

(a)

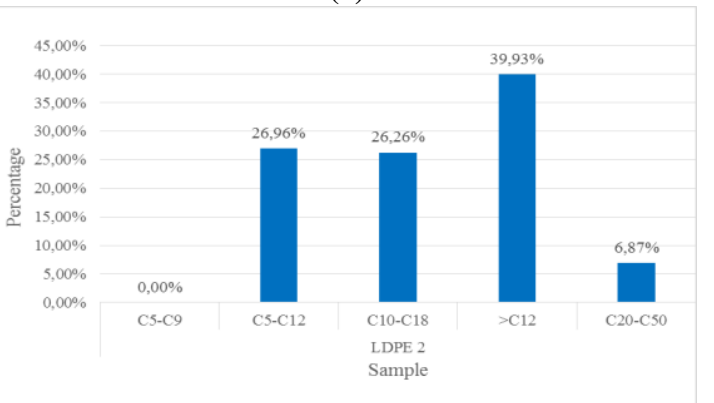

(b)

Figure 6. GC-MS results from pyrolysis of LDPE plastic waste (a) Fraction 1 and (b) Fraction 2

dominated by kerosene (C10-C18) as much as $52.76 \%$, gasoline (C5-C12) as much as $28.94 \%$, diesel oil (> C12) as much as $15.96 \%$, and heavy oil (C20-C50) as much as $2.33 \%$. In Figure $6 \mathrm{~b}$, the content of the fraction 2 from the pyrolysis of LDPE plastics waste was proven to be dominated by diesel oil (> C12) as much as $39.93 \%$, gasoline (C5-C12) as much as $26.96 \%$, kerosene (C10$\mathrm{C} 18)$ as much as $26.26 \%$, and heavy oil (C20-C50) as much as $6,87 \%$. The $\mathrm{C} 5-\mathrm{C} 12$ chain is classified as gasoline, $\mathrm{C} 10-\mathrm{C} 18$ is classified as kerosene, > $\mathrm{C} 12$ is classified as diesel oil, and C20-C50 is classified as heavy oil [9].

In Figure 7, the results of pyrolysis of LDPE plastic waste also produced black activated carbon. The activated carbon produced in the pyrolysis was 19 grams.

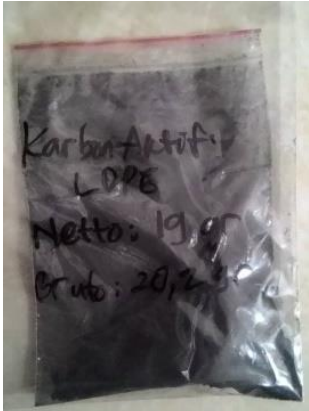

Figure 7. The results of Activated Carbon from pyrolysis oil of LDPE plastics waste

\section{CONCLUSION}

The product of $5 \mathrm{~kg}$ pyrolysis HDPE are 3.25 litres of naphta; 0.85 litre of gasoline; 0.325 litre of diesel fuel; and 18.06 grams of active carbon. Then The product of 5 $\mathrm{kg}$ pyrolysis LDPE are 2.9 litres of gasoline, 0.1 litre of diesel fuel, and 19 grams of active carbon. Composition of fuels from polyethylene (HDPE and LDPE) pyrolysis were naphta, gasoline, and active carbon as residues.

\section{REFERENCES}

1. Jambeck, J.R., Geyer, R., Wilcox, C., Siegler, T.R., Perryman, M., Andrady, A., Narayan, R. and Law, K.L., 2015, Plastic waste inputs from land into the ocean, Science, 347(6223), pp.768-771.

2. Ferroukhi, R., Khalid, A., Lopez-Pena, A. and Renner, M., 2017, Renewable energy and jobs: annual review 2015, International Renewable Energy Agency (IRENA).

3. Patni, N., Shah, P., Agarwal, S. and Singhal, P., 2013, Alternate strategies for conversion of waste plastic to fuels, ISRN Renewable Energy, 2013, pp.1-7.

4. Yadav, R.K. and Yogesh, K.T., 2016, Parametric optimisation of generated waste plastic fuel parameters with the help of taguchi method, International Journal of Mechanical Engineering and Technology (IJMET), 7(1), pp.172-179.

5. Desai, S.B. and Galage, C.K., 2015, Production and analysis of pyrolysis oil from waste plastic in Kolhapur city, International Journal of Engineering Research and General Science, 3(1), pp.590-595.

6. Juliastuti, S.R., 2015, April. Pengolahan Limbah Plastik Kemasan Multilayer Ldpe (Low Density Poly Ethilene) dengan Menggunakan Metode Pirolisis Microwave, In Seminar Nasional Teknik Kimia Kejuangan, pp. 1-11.

7. Ramadhan, A. and Ali, M., 2012, Pengolahan sampah plastik menjadi minyak menggunakan proses pirolisis, Jurnal Ilmiah Teknik Lingkungan, 4(1), pp.44-53.

8. Khan, M.Z.H., Sultana, M., Al-Mamun, M.R. and Hasan, M.R., 2016, Pyrolytic waste plastic oil and its diesel blend: fuel characterization, Journal of environmental and public health, 2016, pp.1-6. 
حكيده

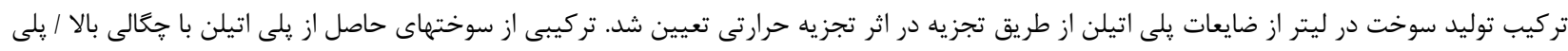

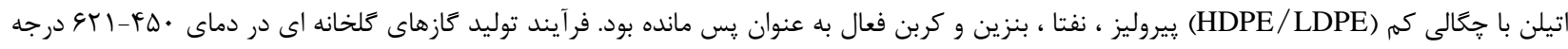

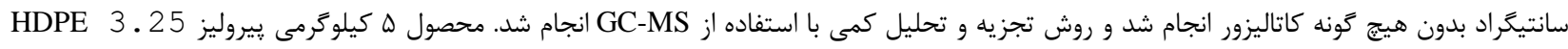

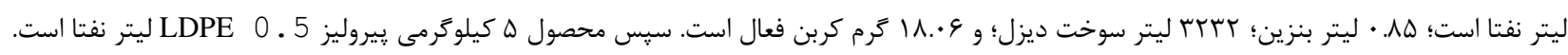

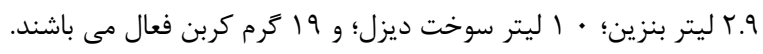

